constitutes the surface, the thickness of which is the socalled radius of molecular attraction. If the magnitude of that radius were known, the average longitudinal tension per unit of area parallel to the surface in the outer layer of liquid could be calculated. We hope before long to apply several tests as to whether the thickness of a black soap film is or is not less than twice the radius of molecular attraction. Various considerations, the discussion of which we defer, indicate that it is not much less, while if the size of an atom approaches Sir William Thomson's lower limit it is probably much greater. If, however, we assume that the thickness of the thinnest film measured by us, say $7 \cdot 2 \times 10^{-7} \mathrm{~cm}$, was just equal to twice the radius of molecular attraction, it follows that the average stress parallel to the surface must be $2 \times 57 / 7^{\circ} 2 \times 10^{-7}=1 \cdot 6 \times 10^{8}$ dynes per square centimetre. This tension is eight times greater than that required to tear brick or cement asunder (cf. Everett's "Units and Physical Constants," p. 56), and one-half of that required to tear cast tin. If the radius of molecular attraction is the same for all substances, the stress in the surface of mercury in contact with air must be nearly ten times greater than in liquide glycérique, or one-fifth of the tension required to rupture steel bars. If the radius is less than half the thickness of the black films, these tensions would be greater.

In many of the ordinary calculations on capillarity the surface tension is treated as acting in a surface of infinite tenuity. In reality it acts in the matter of a liquid shell of small but definite thickness. Our experiments prove that the average magnitude of the stress in this shell is at least of the same order as that required to rupture the less tenacious metals.

A. W. REINOLD

A. W. RÜCKER

\section{JAPANESE LEARNED SOCIETIES}

NEARLY two years ago we described in NATURF a few of the principal of the scientific and learned organisations which had sprung up in recent years in Japan, in imitation of the societies of western countries. The faculty for combination and organisation would appear to be possessed in a high degree by the Japanese, for on all hands we find them establishing societies for political, self-help, philanthropic, industrial, commercial, scientific, and literary purposes. The comparative infancy of the press, and the consequent slowness and difficulty of the interchange of ideas, have rendered these organisations of great value in the social and political life of the country. The extent to which they have spread into every department of national life is well shown by a paper recently contributed by Herr P. Mayet to the Transactions of the German Asiatic Society of Fapan, to which we are indebted for most of the facts in this article. Societies for philantbropic and political purposes, though probably more numerous and powerful than any others, are entirely omitted as beside the present purpose, which is to show how the thirst for knowledge and research is penetrating everywhere amongst this interesting people. It is important, too, to note that these societies are everywhere fostered and promoted by the leading men of the country, including most of the Imperial princes and the Ministers of State, and that they appear to be due in all cases except one to native initiation, unassisted by foreigners. The exception is the Seismo logical Society, which owes its existence and its excellent work to the efforts of Prof. Milne of the Engineering College of 'Tokio. Recently, as we learn from Herr Mayet, a Japanese section of this society has been formed, with numerous native members, papers in Japanese, and a native journal containing original as well as translated contributions. Three of the societies at present in existence have come down from ancient times. These are the Numismatic and Archæological Societies, and an association of $G$ o players, similar to our own chess clubs. A society for the protection and restoration of ancient buildings, nearly all of which are naturally temples, has recently been founded, with the energetic support of the present Foreign Minister. As might have been expectef, there is a society for the cultivation of Chinese literature; but the more practical spirit of Young Japan is exhibited in the association for propagating the employment of the kana or syllabaries in Japanese literature. The importance of the object of this society will be evident when it is mentioned that a Japanese boy of the scholarly class takes from five to seven years to learn the sounds of the Chinese characters, and then he has to commence to learn their meaning. Herr Mayet well observes that so long as the Japanese youth are so heavily handicapped in the race for knowledge they can hardly hope for victory against western lads, who, according to this writer's estimate, are at twelve years of age nearly six years in advance of the Japanese boy of the same age. To remove this obstacle by the employment of the system of forty-seven syllables, now in use in books intended for the common people, is the object of this society, which has for president the Vice Finance Minister. Passing over some art societies, we come to two intended for the cultivation of the French and German languages respectively. One of these is honoured by the support of an Imperial prince. The French Society is working on a French-Japanese dictionary, while both aim at the publication of translations from useful works in these languages. Those hitherto published appear to deal chiefly with political science, a study which appears to attract much of the energy and intellect of the rising generation. A Statistical Society appears also to be very successful, with its periodical publication. The Polytechnic Association has for its object the extension of knowledge with regard to mechanical inventions, and their application to the increase of production in Japan. Agricultural, dendrological, and forestry societies are also in existence, and we may specially note, as a result of the recent Fisheries Exhibition in Berlin, the establishment of a society for the study and improvement of the Japanese fisheries. Many of these associations are, it will be observed, exceedingly practical in their aims, and if the members can succeed in having their discussions and researches circulated among the people, much good will undoubtedly result. The Geographical Society of Tokio has been frequently mentioned in these columns, but there is also a Biological Society under the presidency of the native Professor of Zoology in the University of Tokio. Medical societies also are numerous, whether for purposes of study or to afford aid and relief to the indigent sick. The society for the collection and publication of books with regard to domestic industries must be of much public utility. Of a more purely scientific cast is the association for publishing a dictionary of technical terms in various departments of science and the mechanical arts. The process of finding these termini technici is far from an easy one. They have to be obtained from the Chinese, and have frequently, perhaps generally, to be manufactured by combinations of the Chinese ideographic signs, which often have but a strained or fancied resemblance to the object to be named.

In concluding his paper Herr Mayet says: "Our glance at the Japanese societies of Tokio exhibits a wealth of active ideal life and earnest endeavour. A warm patriotic pulsation is perceptible everywhere, and gives an assurance of the healthiness of the Japanese popular mind. We have here, it is true, only the beginning of association, but it promises much, and the movement will undoubtedly be a constantly growing one." After all, however, the ultimate value of any learned society is measured by the work which it has done, and we have as yet but little opportunity of applying this test to the associations of Japan. 